\title{
THE THERAPEUTIC EFFECT OF HUANGLIAN JIEDU DECOCTION ON ALZHEIMER'S DISEASE BY REGULATING PHAGOCYTOSIS INDUCED BY A $\beta$ IN BV-2 MICROGLIAL CELLS
}

\author{
JUNLI WANG $^{\#}$, WEI SHAO ${ }^{\#}$, YUN YANG, WEIDONG LUO, GUOHUA CHEN * \\ Department of Neurology, Wuhan Hospital of Traditional Chinese and Western Medicine (Wuhan First Hospital), Wuhan, \\ 430022, Hubei, China
}

*corresponding author: chenguohuahbc@126.com

${ }^{*}$ Authors with equal contribution.

Manuscript received: January 2021

\begin{abstract}
This study aimed to investigate the effect of Huanglian Jiedu Decoction on amyloid beta (A $\beta$ ) phagocytosis in BV -2 microglial cells and its regulation on Trem2 protein expression and secretion. BV-2 cells were cultured with different doses of Huanglian Jiedu Decoction. The A $\beta$ phagocytosis of BV-2 cells was determined by flow cytometry. Western blot was used to detect the Trem 2 protein expression in BV-2 cells. The A $\beta$ phagocytosis in BV-2 cells after Trem2 knockout was compared. The results showed that $10 \mu \mathrm{M}$ and $20 \mu \mathrm{M}$ Huanglian Jiedu Decoction significantly promoted the A $\beta$ phagocytosis of BV-2 cells compared with the control group. The expression of Trem2 protein in BV-2 cells in 5 and $10 \mu \mathrm{M}$ Huanglian Jiedu Decoction groups was slightly increased compared with the control group, but without reaching the statistical significance. The expression of Trem 2 protein in $20 \mu \mathrm{M}$ dose group was significantly increased compared with control group. In conclusion, Huanglian Jiedu Decoction can promote the A $\beta$ phagocytosis in BV-2 cells by upregulating the expression of Trem2 protein expression in a dose-dependent manner.
\end{abstract}

\section{Rezumat}

Studiul a investigat efectul decoctului Huanglian Jiedu asupra fagocitozei beta-amiloidice (A $\beta$ ) în celulele BV-2 microgliale precum și reglarea expresiei și a secreției proteinei Trem2. Celulele BV-2 au fost cultivate folosind diferite doze din decoctul Huanglian Jiedu, iar fagocitoza a fost determinată prin citometrie în flux, după eliminarea celulor Trem2. Metoda Western-blot a fost folosită pentru evaluarea expresiei proteinei Trem2 asupra celulelor BV-2. Rezultatele au arătat că decoctul în concentrație de $10 \mu \mathrm{M}$ și $20 \mu \mathrm{M}$ a accelerat fagocitoza $\mathrm{A} \beta$ asupra celulelor BV-2 comparativ cu grupul control. Expresia proteinei Trem2 în celulele BV-2 în grupurile tratate cu decoctul Huanglian Jiedu în concentrație de 5 și respectiv $10 \mu \mathrm{M}$ a fost ușor crescută comparativ cu grupul control, dar fără semnificație statistică. Expresia proteinei Trem2 în grupul tratat cu o doză de $20 \mu \mathrm{M}$ a fost semnificativ crescută comparativ cu grupul control. Decoctul Huanglian Jiedu poate determina fagocitoza A $\beta$ în celulele BV-2 prin reglarea pozitivă a expresiei proteinei Trem2 în manieră doză-dependentă.

Keywords: Alzheimer's disease, microglia, cell phagocytosis, Trem2, A $\beta$

\section{Introduction}

Alzheimer's disease (AD) is a progressive neurodegenerative disease in which patients show progressive loss of cognitive function manifested by loss of memory, abnormal mood, personality changes, impaired thinking, impaired orientation and impaired judgement. They gradually lose their ability to take care of themselves, lose all functions of the body, and finally die [1]. Currently, Alzheimer's disease is the common form of dementia contributing to $60-70 \%$ of all cases. The global number of dementia patient has reached 55 million, and it is estimated that by 2050, the number of global dementia will reach 139 million. Currently, dementia is the seventh cause of death among all diseases, having a high psychological, social and economic impact. No current treatment can cure AD or other forms of dementia, they only can limit the progression of the disease to some extend [2]. The main pathological manifestations of $\mathrm{AD}$ are senile plaques formed by deposition of amyloid beta-protein $(\mathrm{A} \beta)$ in the brain, neurofibrillary tangles caused by hyperphosphorylation of tau protein and gradual loss of cholinergic neurons. At present, there are many different theories about the pathogenesis of $\mathrm{AD}$, among which $A \beta$ toxicity theory is considered to be the most mainstream pathogenesis theory. The theory states that $\mathrm{A} \beta$ is the most core cause of $\mathrm{AD}$, causing a series of downstream cascade reactions, leading to neuron damage, thus inducing dementia [3]. Although, the theory of $A \beta$ is still widely accepted, the strategy of using $A \beta$ as a therapeutic target has always failed. The level of $A \beta$ in the brain is in the dynamic balance of generation and clearance. The production of $A \beta$ is only one of the factors that determine the level of $A \beta$ in the brain, and on the other hand, the clearance of 
$\mathrm{A} \beta$ is also an important factor to determine the level of $A \beta$ [4]. Moreover, as the production level of $A \beta$ is mostly determined by the variant genotype, the acquired factors have little influence on it. The enhanced clearance of $A \beta$ is particularly important to reduce the level of $A \beta$ in the brain. Although neurons and astrocytes have a phagocytic effect on $A \beta$, microglia are the main cells responsible for the immune function in the brain. In the process of microglia swallowing $A \beta$, the release of related cytokines is also closely related to the pathogenesis of AD [5]. In traditional Chinese medicine, Alzheimer's disease belongs to the category of stagnation syndrome, forgetfulness syndrome, wenzhitong syndrome, shendai, language reversal, depression syndrome, mania syndrome and so on [6]. The progression of AD can be divided into early, middle and late stages. The early stage of dementia is kidney deficiency [7]. On the basis of the aggravation of amnesia, the patients in the middle stage have abnormal emotional behaviours. Traditional Chinese medicine believes that this period should be attributed to kidney deficiency for a long time, with the accumulation of pathogenic factors and disturbing the mind. It is appropriate to pay equal attention to expelling pathogenic factors and strengthening the body. At the end of the disease, the patient had a high degree of mental retardation, is speechless, unable to move, belonging to the extreme of deficiency of essence, and eventually died of Yin and Yang separation [8].

After pharmacological analysis, some drugs or several plants extracts reach in apigenin, berberine, crocin, epigallocatechin gallate, genistein, ginsenoside Rh1, hesperidin, iso-quercitrin, linalool, naringenin, quercetin, rutin, silibinin, showed their efficacy in ameliorating the progression and symptoms of $\mathrm{AD}$ [9-12]. Huanglian Jiedu Decoction is a traditional Chinese medicine recipe that contained rhizoma of Coptis chinensis, Ranunculaceae, radix of Scutellaria baicalensis, Lamiaceae, cortex of Phellodendron chinense, Rutaceae and fructus of Gardenia jasminoides, Rubiaceae in a ratio of $3: 2: 2: 3$. It is used as a heat clearing agent, which has the effect of clearing heat and detoxification, and mainly treats the syndrome of Triple Energizer fire and toxin. Clinical commonly used in the treatment of sepsis, sepsis, dysentery, pneumonia, urinary tract infection, epidemic cerebrospinal meningitis, Japanese encephalitis [13]. Huanglian Jiedu decoction has been used in the treatment of mid-term AD patients, but its molecular mechanism has not been clearly studied [14]. Therefore, this study intends to explore the efficacy of Huanglian Jiedu Decoction in the treatment of Alzheimer's disease and clarify its mechanism of action.

\section{Materials and Methods}

\section{Animals}

BV-2 cells (C57BL/6 mouse brain microglia cells (immortalized)) were provided from China typical culture preservation centre of Wuhan University (Resource number: 3142C0001000000337). Huanglian Jiedu Decoction: rhizome of Coptis chinensis, radix of Scutellaria baicalensis, cortex of Phellodendri chinense and fructus of Gardenia jasminoides were purchased from Hubei Tianji Chinese Herbal Pieces Co., Ltd., China. Huanglian Jiedu Decoction was prepared by the Centre of Wuhan First Hospital, China and met the standard of Pharmacopoeia of the People's Republic of China (2010 Edition). After soaking in the ratio of $3: 2: 2: 3$ of the original formula, extract 3 times at $120^{\circ} \mathrm{C}$, add 10,8 and 8 times of water each time, soak for $30 \mathrm{~min}$ before decocting, and decoct for $2 \mathrm{~h}, 1.5 \mathrm{~h}$ and $1.5 \mathrm{~h}$ in turn. The three extracts were mixed and concentrate till $0.6 \mathrm{mg} / \mathrm{mL}$. Dulbecco's Modified Eagle Medium (DMEM) (high glucose), trypsin and foetal bovine serum (FBS) were purchased from Gibco ${ }^{\mathrm{TM}}$, Thermo Fisher Scientific, USA. CCK-8 (cell counting kit-8) kit was purchased from Thermo Fisher, USA. The FAM-Ab42 polypeptide (SigmaAldrich, USA) $(0.5 \mathrm{mg}$ ) was dissolved with $1 \mathrm{~mL}$ TFA (Trifluoroacetic, Labio, China), shaking at room temperature until the solution was transparent, transferred to a $50 \mathrm{~mL}$ centrifugal, and dried in a vacuum dryer. FAM-Ab42 (Sigma-Aldrich, USA) $(0.3 \mathrm{mg})$ was dissolved with $2 \mathrm{~mL}$ of FHIP (FTS and Hook-interacting protein, Biological, USA), and then quickly divided into 20 sterile centrifuge tubes of $1.5 \mathrm{~mL}$, each tube was dried with a vacuum dryer, and then sealed with lids and lids, and stored away from light at $-20^{\circ} \mathrm{C}$. Before use, each tube was dissolved with $26.25 \mu \mathrm{L}$ DMSO (dimethyl sulfoxide) (Sigma, USA). When in use, add the complete medium and dilute to the working concentration of $500 \mathrm{nM}$. Cell culture

BV-2 microglia cells were cultured in complete medium containing $10 \%$ FBS and cultured in cell incubator $\left(37^{\circ} \mathrm{C}, 5 \% \mathrm{CO}_{2}\right)$. When the cells reached $90 \%$ fusion state, $0.25 \%$ membrane enzyme was added and digested in the incubator for 5 minutes. The digestion was terminated by adding the complete culture medium. The cells were passaged or used in experiments according to the ratio of 1:3.

Method and dose of administration

After the cells reached $90 \%$ fusion, they were digested and inoculated into 96 well plates with 5000 cells per well. After adhering to the wall in the incubator for $24 \mathrm{~h}$, different concentrations of Huanglian Jiedu Decoction concentrate were added. Four different concentrations of $0,5 \mu \mathrm{M}, 10 \mu \mathrm{M}, 20 \mu \mathrm{M}$ were selected for intervention (the corresponding concentration of DMSO was used as the blank control group), with three holes in each group. After adding drugs, they 
were put into the incubator for $24 \mathrm{~h}$. After $24 \mathrm{~h}$ of intervention, the medium was sucked out, the cells were cleaned by DMEM twice, and $0.1 \mathrm{~mL}$ DMEM was added into each well for $3 \mathrm{~h}$. The cell supernatant was collected for detection of sTrem2, and the total protein was collected by cell lysis.

Flow cytometry

After $24 \mathrm{~h}$ of intervention with different concentrations of Huanglian Jiedu Decoction and blank DMSO, the entire medium in each well was aspirated, and the FAM-Ab42 solution of $500 \mu \mathrm{M}$ concentration was added, and the solution was incubated for 2 hours at $37^{\circ} \mathrm{C}$. The FAM-Ab42 solution was aspirated, and PBS (phosphate-buffered saline) was added slowly for 2 times at $37^{\circ} \mathrm{C}$ to remove the residual FAM-Ab42 which was not phagocytized outside the cell. $150 \mu \mathrm{L}$ trypsin was added into each well and incubated for 5 min at $37^{\circ} \mathrm{C} .1 \mathrm{~mL}$ of complete medium was added into each well to terminate digestion. The entire medium in each well was transferred to a $1.5 \mathrm{~mL}$ centrifuge tube and centrifuged at $500 \mathrm{~g}$ for $3 \mathrm{~min}$ to remove the supernatant, and $1 \mathrm{~mL}$ ice PBS was added for washing twice. $500 \mu \mathrm{L}$ ice PBS was added into each ionophore until the cells were evenly suspended without obvious aggregation. Flow cytometry (LSR Fortessesx-20, purchased from BD-Biosciences) was used. Before the detection, $50 \mu \mathrm{L}$ of $0.4 \%$ trypan blue solution (Sigma-Aldrich, USA) was added to neutralize a small amount of FAM-Ab42 which was not removed outside the cell, to avoid affecting the detection results. The number of cells per tube was set to 10000 . The main index of detection was the number of cells with green fluorescence/total number of cells detected.

Supernatant collection and cell protein extraction The supernatant was collected in a $1.5 \mathrm{~mL}$ centrifuge tube and put into a refrigerator at $4{ }^{\circ} \mathrm{C}$ for standby. After the supernatant was collected, the cells were rinsed with PBS on ice for 2 times, and the residual PBS was washed with a pipette gun. Then the 6-well plate was placed on the ice, and the t-fertilizer lysate of ice was added into each well and incubated for 30 minutes at $4^{\circ} \mathrm{C}$ to make the cells fully lysed. The 6-well plate was put on the ice, scrape off the cells with a cell scraper, and transfer to a $1.5 \mathrm{~mL}$ pre-cooled centrifuge tube with a pipette gun, and then put in the centrifuge tube into a $4^{\circ} \mathrm{C}$ shaking table and incubate for $30 \mathrm{~min}$. The supernatant was centrifuged at $4^{\circ} \mathrm{C}$ and $12000 \mathrm{rpm}$ for $10 \mathrm{~min}$ and collected for quantitative analysis of proteins by BCA (bicinchoninic acid assay). siRNA transfection

Cell planning before transfection: BV-2 cells in the logarithmic growth phase were inoculated into two 6 -well plates with $2.5 * 10^{5}$ cells per well and incubated at $37^{\circ} \mathrm{C}$ in $5 \% \mathrm{CO}_{2}$ saturated humidity incubator for $12 \mathrm{~h}$. The experiment was divided into two groups: Trem2 siRNA group and control RNA group, with 6 wells in each group. The transfection methods were detailed in the instructions of the Lipo2000 transfection kit (Sigma-Aldrich, USA). After 48 hours of siRNA silencing, six wells in the Trem2 siRNA group were divided into two groups with three complex pores in each group. One group was added with Huanglian Jiedu Decoction of $20 \mu \mathrm{M}$ concentration, the other group was added with the corresponding concentration of DMSO; the control siRNA group was also divided into two groups, adding $20 \mu \mathrm{M}$ Huanglian Jiedu decoction or corresponding concentration DMSO. Four groups were recorded as siRNA, siRNA + Huanglian Jiedu Decoction, control, control + Huanglian Jiedu decoction. After adding the corresponding drugs, they were put into incubator at $37^{\circ} \mathrm{C}$ for $24 \mathrm{~h}$.

Western blot assay

Sample loading: the $4-20 \%$ prefabricated gel in electrophoresis buffer was used and load the sample according to the protein amount of $30 \mu \mathrm{g}$ per well. Three compound holes in each group were set up.

Electrophoresis: the power supply was connected according to the positive and negative electrodes and adjusted the voltage value at $120 \mathrm{~V}$. The electrophoresis was stopped when the electrophoresis was closed to the bottom of the prefabricated rubber. Membrane transfer: put the cut size and preformed glue and the corresponding PVDF membrane into methanol for moistening and washing, and then take them out and soak them in the electrokinetic buffer for standby. Take out the preformed glue, cut it to a proper size, and then use the prefabricated glue, sponge, filter paper and PVDF membrane to make the electrorotary sandwich. After each layer is laid, clamp the clamp, put it into the electric rotating trough in the correct way, put it into the ice box, and connect the power supply. The current modulation is $380 \mathrm{~mA}$ and the time is set to $100 \mathrm{~min}$. Antibody hybridization: after membrane transfer, PVDF membrane was put into 5\% skimmed milk powder and sealed for 45 minutes, then washed with pure water, then added into diluted primary antibody-Trem 2 (Invitrogen, USA, 1:1000) and $\beta$-actin (Cell Signaling, USA, 1:1000), and incubated overnight at $4^{\circ} \mathrm{C}$ shaking table. The PVDF membrane was washed twice in PBST for $15 \mathrm{~min}$ each time. Goat antiMouse $\operatorname{IgG}(\mathrm{H}+\mathrm{L})$ secondary antibody (Invitrogen, 31430 , USA) diluted with skim milk powder was incubated at room temperature for 1 hour, and the membrane was washed twice by PBST for 15 min each time. Imaging: mix ECL solution A and B (Vazyme, China) at a ratio of 1:1, take out PVDF film, drain PBST, add ECL light-emitting liquid evenly onto the film, cover PVDF film with preservative film, and image in dark room. The scanner scanned the film to the computer, and used Image-J analysis software to measure the optical density.

Statistical analysis

Graphpad Prism 6.0 software was used to calculate the mean value \pm standard deviation of 3 complex 
holes in each group. Single-factor analysis of variance was used in different groups. The difference was statistically significant $(\mathrm{p}<0.05)$.

\section{Results and Discussion}

The effect of Huanglian Jiedu Decoction on $A \beta$ phagocytosis in BV-2 cells

Compared with the control group, the phagocytosis of BV-2 cells in the $5 \mu \mathrm{M}$ Huanglian Jiedu Decoction group was slightly higher compared with the control group, but without reaching the statistical significance ( $p>0.05)$. However, compared with the control group, $10 \mu \mathrm{M}$ and $20 \mu \mathrm{M}$ Huanglian Jiedu Decoction
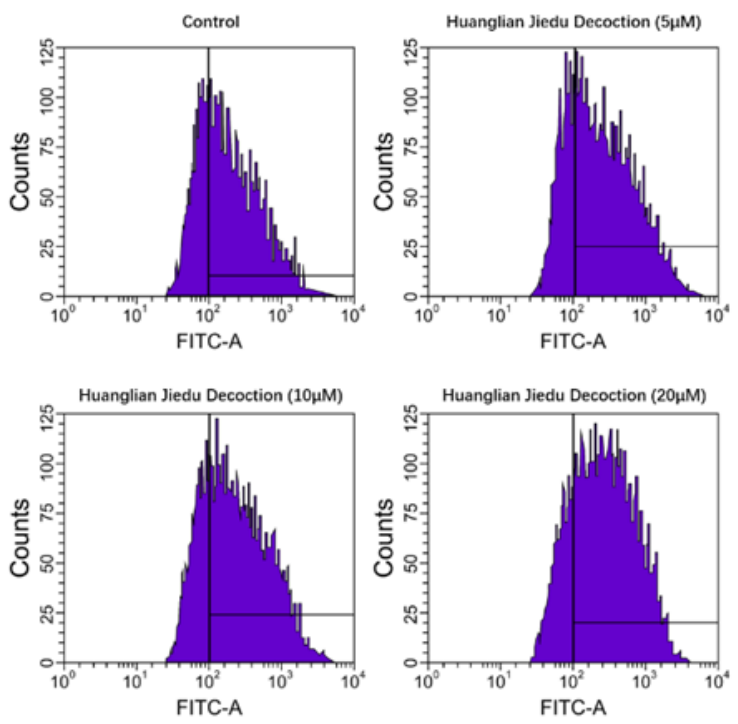

determined a significant increase in the phagocytosis of BV-2 cells $(* \mathrm{p}<0.05, * * \mathrm{p}<0.01)$ (Figure 1).

Huanglian Jiedu Decoction can promote the expression of Trem2 in BV-2 cells

The grey value analysis of terms and $\beta$-actin protein bands was performed to calculate the relative protein expression of Trem2 (Trem2/e-actin). The results showed that the relative expression of Trem 2 protein in BV-2 cells was increased by $5 \mu \mathrm{M}$ and $10 \mu \mathrm{M}$ Huanglian Jiedu Decoction, but without reaching the statistically significant difference compared with the control group ( $p>0.05$ ) (Figure 2$)$. The relative expression of Trem2 protein in BV-2 cells was significantly increased in the $20 \mu \mathrm{M}$ dose group compared with the control group $(\mathrm{p}<0.05)$.

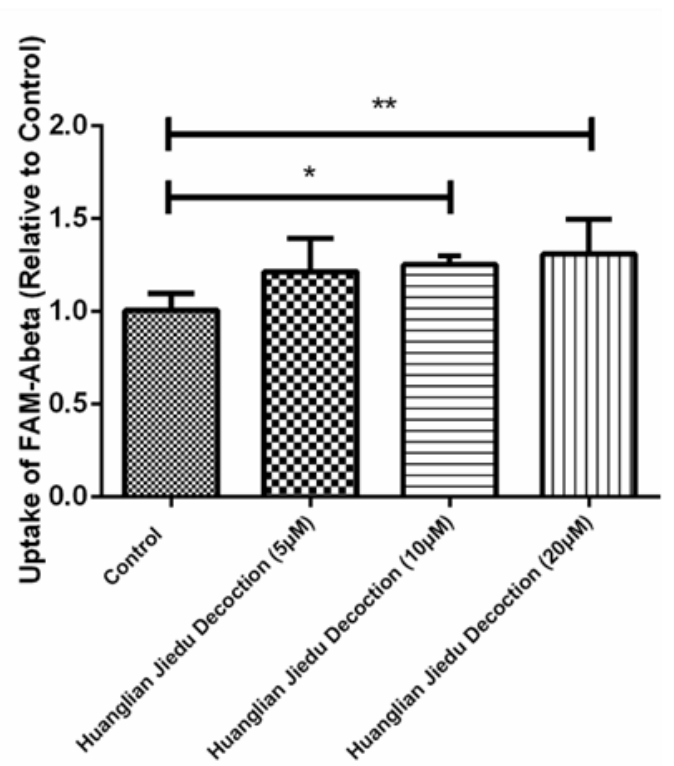

Figure 1.

The effect of different doses of Huanglian Jiedu Decoction on A $\beta$ phagocytosis of BV-2 cells Compared with the control group: ${ }^{*} \mathrm{p}<0.05,{ }^{* *} \mathrm{p}<0.01$

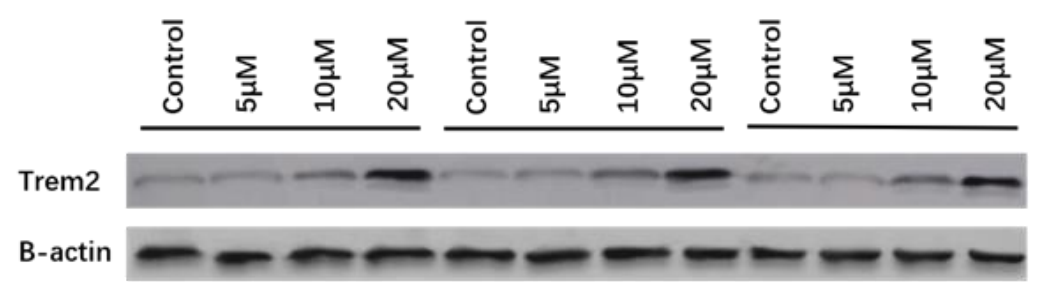

Figure 2.

The effect of different doses of Huanglian Jiedu Decoction on the expression of Trem2 protein in BV-2 cells Compared with the control group $* * \mathrm{p}<0.01$

Effect of Huanglian Jiedu Decoction on the expression of Trem2 protein after Trem2 gene silencing

After gene silencing, the expression of Trem2 protein in gene silencing group was significantly lower than that in blank control group $(\mathrm{p}<0.05)$ and it was not promoted after the treatment with $20 \mu \mathrm{M}$ Huanglian Jiedu decoction $(\mathrm{p}>0.05)$ (Figure 3). Compared with the blank control group, the expression of Trem 2 was 
significantly increased in the control group treated with $20 \mu \mathrm{M}$ Huanglian Jiedu Decoction $(\mathrm{p}<0.05)$. After siRNA transfection, there was no significant difference in the $A \beta$ phagocytosis between the four groups $(\mathrm{p}>0.05)$ (Figure 4).

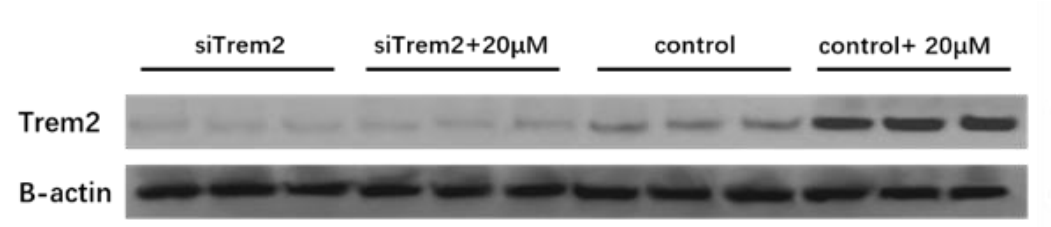

Figure 3.

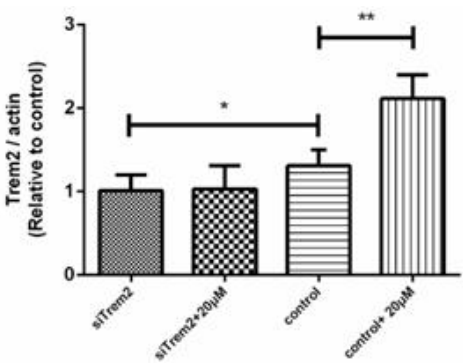

The effect of Huanglian Jiedu Decoction on the expression of Trem2 protein after Trem 2 gene silencing
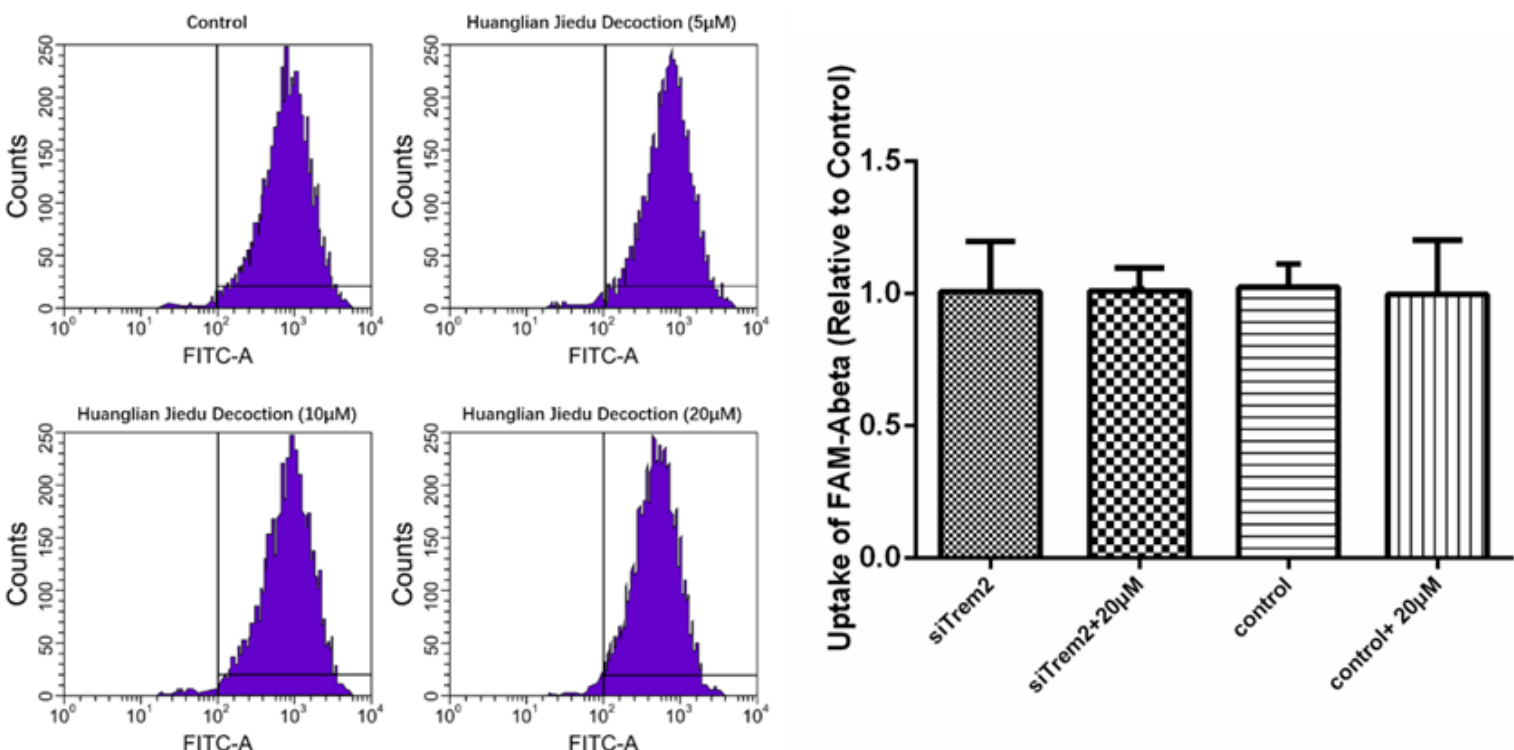

Figure 4.

Effect of Huanglian Jiedu Decoction on A $\beta$ phagocytosis of BV-2 cells after TREM2 gene silencing

BV-2 cell is an immortalized mouse microglia, which is widely used in the inflammatory reaction in the brain. This cell line is the most commonly used model cell for the release and swallowing of inflammatory factors [15]. Therefore, we used BV-2 cells to detect the effect of Huanglian Jiedu Decoction on its phagocytic function. The $\mathrm{A} \beta$ phagocytosis was promoted by Huanglian Jiedu Decoction in BV-2 cells in a dosedependent manner. Phagocytosis is one of the main physiological functions of microglia, which plays a key role in various immune related functions. Studies have shown that microglia can quickly respond to pathological stimuli in the brain, and participate in a series of immune responses including pathogen detection, synaptic repair after injury, phagocytosis of apoptotic cells and inflammatory response. In the normal brain, microglia are inactive. They do not phagocytize cells or tissues, but they constantly stretch and stretch the cell processes at a high frequency to explore the surrounding environment. As a result of infection, injury or neurodegenerative disease, microglia will undergo a series of changes in morphology, gene expression and function, from an inactive state to activated state [16]. In this experiment, the addition of $A \beta$ can promote the microglia to transform into activated state, so as to phagocytize $A \beta$.

The expression of Trem 2 plays an important role in the endocytosis of microglia. Previous studies have shown that overexpression of Trem 2 can promote the clearance of t-regulated neurons in primary mouse microglia [17]. However, after gene silencing of Trem2, the ability of scavenging apoptotic neurons is significantly lower than that of the control group. The phagocytic capacity of primary microglia in wild-type mice and Trem2 knockout mice was compared. The phagocytic capacity of primary microglia in Trem 2 knockout mice was significantly decreased [18]. Even if the expression of Trem2 was not interfered with, but DAP12 downstream of Trem2 was selectively inhibited, the phagocytic function of microglia was significantly reduced. It can be seen that Trem 2 and its downstream pathway play an important role in the phago- 
cytosis of microglia. The results of this study can preliminarily conclude that Huanglian Jiedu Decoction can promote the phagocytosis of BV-2 cells by up regulating the expression of Trem2. This is also consistent with the results of other previous literature, where, Trem 2 is shown to play an important role in the phagocytosis of $A \beta$, and up-regulation of Trem 2 can promote the phagocytosis of microglia [19]. There was no significant difference in the phagocytosis of $\mathrm{A} \beta$ by BV-2 microglia among the four groups. The phagocytosis of $\mathrm{A} \beta$ by $\mathrm{BV}-2$ microglia was nearly $100 \%$ of the total number of cells. The reason is that the method of chemical reagent transfection can greatly improve the permeability of cell membrane and promote the endocytosis of cells. At present, the laboratory is carrying out the breeding of Trem 2 gene knockout mice, and the primary microglia of gene knockout mice and wild-type mice are obtained. By comparing the primary cells with the wild-type mice, we can better explore the specific mechanism of Trem 2 mediated peak swallowing.

\section{Conclusions}

Huanglian Jiedu Decoction can promote the $A \beta$ phagocytosis in $B V-2$ cells $A \beta$ by upregulating the expression of Trem 2 protein expression in a dosedependent manner. Further clinical studies should be done in order to evaluate the beneficial effects also in $\mathrm{AD}$ patients.

\section{Acknowledgement}

This work was supported by National natural science foundation of China (81673914).

\section{Conflict of interest}

The authors declare no conflict of interest.

\section{References}

1. Lim S, Mohaimin S, Min D, Roberts T, Sohn YJ, Wong J, Sivanesathurai R, Kwon SC, Trinh-Shevrin C, Alzheimer's Disease and its Related Dementias among Asian Americans, Native Hawaiians, and Pacific Islanders: A Scoping Review. J Alzheimers Dis., 2020; 77(2): 523-537.

2. Purza L, Abdel-Daim M, Belba A, Iovan C, Bumbu A, Lazăr L, Bungău S, Țiț DM, Monitoring the effects of various combination of specific drug therapies at different stages of Alzheimer's dementia. Farmacia, 2019; 67(3): 477-481.

3. Roldán-Peña JM, Romero-Real V, Hicke J, Maya I, Franconetti A, Lagunes I, Padrón JM, Petralla S, Poeta E, Naldi M, Bartolini M, Monti B, Bolognesi ML, López Ó, Fernández-Bolaños JG. Tacrine-Oprotected phenolics heterodimers as multitarget-directed ligands against Alzheimer's disease: Selective subnanomolar BuChE inhibitors. Eur J Med Chem., 2019; 181: 111550: 1-16.
4. Lin L, Lv S, Liang J, Li H, Xu Y, Level of knowledge about Alzheimer's disease among nursing staff in Suzhou and its influencing factors. Curr Alzheimer Res., 2019; 16(7): 650-658.

5. Cai Z, Hussain MD, Yan LJ, Microglia, neuroinflammation, and beta-amyloid protein in Alzheimer's disease. Int J Neurosci., 2014; 124(5): 307-321.

6. Ifrim-Chen F, Dragoș D, Moga M, Barbilian A, Lupuşoru M, Oproiu AM, Edu A, Gilca M, "Ectopic" gustative and olfactory receptors in the brain - new targets for neurodegeneration therapy? Farmacia, 2019; 67(1): 34-42.

7. Bugnicourt JM, Godefroy O, Chillon JM, Choukroun G, Massy ZA, Cognitive disorders and dementia in CKD: the neglected kidney-brain axis. J Am Soc Nephrol., 2013; 24(3): 353-363.

8. Vanderschaeghe G, Vandenberghe R, Dierickx K, Stakeholders' Views on Early Diagnosis for Alzheimer's Disease, Clinical Trial Participation and Amyloid PET Disclosure: A Focus Group Study. J Bioeth Inq., 2019; 16(1): 45-59.

9. Sharifi-Rad M, Lankatillake C, Dias DA, Docea AO, Mahomoodally MF, Lobine D, Chazot PL, Kurt B, Tumer TB, Moreira AC, Sharopov F, Martorell M, Martins N, Cho WC, Calina D, Sharifi-Rad J, Impact of natural compounds on neurodegenerative disorders: from preclinical to pharmacotherapeutics. J Clin Med., 2020; 9(4): 1061: 1-19.

10. Islam MS, Quispe C, Hossain R, Islam MT, Al-Harrasi A, Al-Rawahi A, Martorell M, Mamurova A, Seilkhan A, Altybaeva N, Abdullayeva B, Docea AO, Calina D, Sharifi-Rad J, Neuropharmacological effects of quercetin: a literature-based review. Front Pharmacol., 2021; 12: 665031: 1-16.

11. Popescu IA, Donea C, Lupuleasa D, Nicoară AC, Popa DE, Miron DS, Rădulescu FȘ, Comparative assessment of the in vitro performance for modified release tablets containing pentoxifylline using paddle method and flowthrough cells. Farmacia, 2015; 63(6): 903-908.

12. Tataringa G, Stan C, Mircea C, Zbancioc AM, Novel therapeutic options for old drugs. Rev Med Chir Soc Med Nat Iasi, 2019; 123(2): 364-372.

13. Gao SJ, Zhao JY, Xu XY, Xu WX, Wang L, Chen GR, Study on anti-systemic inflammatory response syndrome activity of Huanglian Jiedu Decoction. $J$ Pharm Res., 2018; 37: 13-15.

14. Gu XR, Fang SY, Ren W, Wang HJ, Yang J, Si N, Bian BL, Zhao HY, Pharmacodynamics of Huanglian Jiedu decoction in Alzheimer's disease (AD) model rats and effect on improvement of inflammation microenvironment in brain. Zhongguo Zhong Yao Za Zhi, 2018; 43(14): 3006-3011, (available in Chinese).

15. Abbasi MA, Hassan M, Aziz-Ur-Rehman, Siddiqui SZ, Shah SAA, Raza H, Seo SY, Synthesis, enzyme inhibitory kinetics mechanism and computational study of $\mathrm{N}$-(4-methoxyphenethyl)-N-(substituted)4-methylbenzenesulfonamides as novel therapeutic agents for Alzheimer's disease. PeerJ., 2018; 6: e4962: 1-20.

16. Scott MC, Bedi SS, Olson SD, Sears CM, Cox CS, Microglia as therapeutic targets after neurological injury: strategy for cell therapy. Expert Opin Ther Targets, 2021; 25(5): 365-380. 
FARMACIA, 2021, Vol. 69, 5

17. Morrison C, Rabipour S, Knoefel F, Sheppard C, Taler $\mathrm{V}$, Auditory Event-related potentials in mild cognitive impairment and Alzheimer's disease. Curr Alzheimer Res., 2018; 15(8): 702-715.

18. Gorji N, Moeini R, Memariani Z, Almond, hazelnut and walnut, three nuts for neuroprotection in Alzheimer's disease: A neuropharmacological review of their bioactive constituents. Pharmacol Res., 2018; 129: 115-127.
19. de Freitas LV, da Silva CC, Ellena J, Costa LA, Rey NA, Structural and vibrational study of 8hydroxyquinoline-2-carboxaldehyde isonicotinoyl hydrazone--a potential metal-protein attenuating compound (MPAC) for the treatment of Alzheimer's disease. Spectrochim Acta A Mol Biomol Spectrosc., 2013; 116: 41-48. 